\title{
THE INFLUENCE OF ENVIRONMENTAL FACTORS ON ASPERGILLUS NIGER GRANITE WEATHERING
}

\author{
WU, Q. ${ }^{1,2,3}-\mathrm{HU}, \mathrm{H}^{1,{ }^{1 *}}$ \\ ${ }^{I}$ Collaborative Innovation Center of Sustainable Forestry in Southern China of Jiangsu \\ Province, Nanjing Forestry University, 159 Longpan Road, Nanjing, Jiangsu 210037, China \\ ${ }^{2}$ Key Laboratory of Soil and Water Conservation and Ecological Restoration in Jiangsu \\ Province, Nanjing Forestry University, 159 Longpan Road, Nanjing, Jiangsu 210037, China \\ ${ }^{3}$ School of Biological and Food Engineering, Anyang Institute of Technology \\ Anyang, Henan 455000, China \\ *Corresponding author \\ e-mail: 531208831@qq.com \\ (Received 24 $4^{\text {th }}$ Aug 2018; accepted $11^{\text {th }}$ Oct 2018)
}

\begin{abstract}
In order to explore the effects and influence of environmental factors on microbial restoration of waste rock, an efficient rock-weathering strain Aspergillus niger XF-1 was isolated from a granite face. Concentrations of $\mathrm{SiO}_{2}$ in nutrient solution at different temperatures, $\mathrm{pH}$ values, generation cycles, and vaccination quantities were measured using shake flask leaching and inductively coupled plasma optical emission spectrometer (ICP-OES) to analyze the grey correlation degree of weathering. The results reveal that the A. niger XF-1 strain can be used as a good fungal source for the restoration of degraded habitats in abandoned granite areas, and can also be used to promote the release of more Si elements in granite. Moreover, $\mathrm{pH}$ is the dominant factor affecting the weathering of granite by $A$. niger, followed by vaccination quantity and temperature, while generation cycle is the least important factor. The optimum temperature at which granite is weathered by $A$. niger was $28^{\circ} \mathrm{C}$, the most appropriate $\mathrm{pH}$ value was 3 , the most suitable generation was the fifth, and the optimum vaccination quantity was $10^{7}$ (spore numbers $\mathrm{mL}^{-1}$ ).
\end{abstract}

Keywords: Aspergillus niger, weathering effect, fermentation, grey correlation degree analysis

\section{Introduction}

Granite is one of the most widely distributed rocks globally. In developing countries, abandoned granite mines are often covered with bare rock because of artificial overexploitation, which has led to severe soil and water loss, sharp declines in plant diversity, deteriorated ecological conditions, and disastrous mine rocky desertification phenomena (Wu et al., 2017a). As natural rocky desertification restoration is almost impossible, appropriate strategies must be developed that can be applied to artificially promote improvements to degraded ecosystems (Qi et al., 2013). One of the most effective ways to do this is to spray a mixture of plant seeds, soil, and nutrients onto exposed mine rock surfaces (Wu et al., 2017b; Borland et al., 2016). In this process, however, when the plants run out the nutrient matrix layer they die and fall off the rock surface and so this does not form a sustainable soil environment (Pratas et al., 2005). Soil formation is therefore a crucial issue to promote plant growth via the fusion of sprayed materials and the rock surface (Barker and Banfield, 1996).

Rock weathering is a key component of soil formation. As part of research in this area, physicochemical weathering effects are often closely studied (Borland et al., 2016; Wang, 2017; Tang et al., 2016; Cheng et al., 2015); previous research by Kevin et al. 
led to the conclusion that biological weathering plays a prominent role in certain cases in the presence of biological organisms in the environment (Peng et al., 2015; Li et al., $2015 \mathrm{c}$ ). The formation of a soil starts from the moment that various organisms begin to develop within loose rock crevices (Williams and Steinbergs, 1959); microbial weathering in this context is one of the most common geological process on Earth, and mainly controls biofilm formation during growth. The organic acids and other metabolites produced during this process mean that one part of rock mineral substances will dissolve (Lian, 2014). Previous work has shown that microbial activity is one of the most important factors in the weathering of rocks and minerals in the biosphere; for example, Bennett et al. noted that the rock weathering performance of microorganisms is related to metabolic by-products, the limited nutrition that can be extracted from special minerals, and growth and development (Bennett et al., 2001). Thus, Si (silicon), $\mathrm{Al}$ (aluminum), $\mathrm{Fe}$ (ferrum), $\mathrm{Mg}$ (magnesium), $\mathrm{Ca}$ (calcium), and $\mathrm{K}$ (potassium) are dissolved from silicates, aluminosilicates, oxides, phosphates, carbonates, and sulfides during this process (Lian et al., 2008); the various elements that are released also comprise an important nutrient source for plant growth and development. This means that research on microbial weathering rock is one of the important components of ecological environmental restoration, and is therefore of great significance to overall sustainable development.

Bacteria and fungi are able to decompose minerals (Chiang et al., 2014; Li et al., 2015c, 2017; Ramos et al., 2014; Song et al., 2015). In another previous study, Castro et al. compared the ability of the bacteria Pseudomonas, Penicillium, and Aspergillus at promoting $\mathrm{Zn}$ and $\mathrm{Ni}$ dissolution in smithsonite and garnierite and were able to show that the latter was most efficient (Castro et al., 2000). This kind of work was developed by Lian et al. who compared weathering biotite mineral differences between A. niger and the glial species Bacillus; these workers noted that the weathering effect of the former was better, and also noted that $A$. niger played a leading role in the weathering process of biotite via the secretion of acid metabolites. In this case, A. niger-mineral aggregates formed via the extension of hyphae, which then penetrated into microcracks and promoted rock weathering (Dong and Lian, 2014). The original strains Aspergillus niger and Penicillium heteromorphum PHT were studied by diethylsulfate (DES) induced protoplast mutagenesis and bioleaching of potassium-richshale (Tang et al., 2011).

Studies on the potassium-releasing effect and influence of $A$. niger on these minerals (Hu et al., 2011) as well as cleaning effects on quartz sands (Song and Lian, 2014) and promotion effect of plant growth (Lü et al., 2015) have also made some progress. To date, however, the influence of $A$. niger on the weathering of granite has not been discussed. Aspergillus niger XF-1 is a dominant strain isolated from the granite surface in Suzhou, Jiangsu Province, and has a certain relationship with granite weathering. Therefore, it is of great significance to study the unique functions and ecological effects of lithophytic microorganisms.

For the realization of sustainable development of ecological restoration, we screened the efficient strain to weathering granite, and study the effects of environmental factors on the habitat restoration in abandoned rock mining areas. In current study, an efficient strain of A. niger was isolated and purified from the lichen surface of granite rock in this study via preliminary silicon-releasing effect screening. The effect of $A$. niger weathering granite at releasing this mineral was observed under different temperature conditions as well as initial $\mathrm{pH}$ values, generation cycles, and vaccination quantities. 
Results were then analyzed using the grey correlation analysis method (GCAM) in order to understand the degree of importance and relative function of different factors during the weathering process. This enabled a clear scientific basis to be developed to improve weathering effects, promote the greening of abandoned mine rock slopes, soil formation, and improvements to the overall ecological environment.

\section{Material and methods}

\section{Rock samples}

Porphyry granite was used as the source rock for this analysis. All experimental rock samples were obtained from an abandoned granite mine on Jinding Mountain, in Wuzhong district, Suzhou, Jiangsu, China (E 120 $30^{\prime}$, N31 $\left.{ }^{\circ} 17^{\prime}\right)$. Samples were placed in a sterile kraft bag; lichens were stored in a refrigerator at $4{ }^{\circ} \mathrm{C}$, and the remainder were held in a refrigerator at $-20{ }^{\circ} \mathrm{C}$. The fresh rock samples used in this experiment were washed with distilled water, sieved through a 200 mesh after being dried naturally, ground to a particle size $<90 \mu \mathrm{m}$, and then autoclaved at $121^{\circ} \mathrm{C}$ for $20 \mathrm{~min}$.

Dried samples were then evaluated using X-ray fluorescence (XRF) spectrometry; the elements contained within granite are summarized in Table 1. Diffractometer (HX041) analysis showed that the quartz, plagioclase, potassium feldspar, biotite, chlorite or vermiculite accounted for $30-35 \%, 20-25 \%, 25-30 \%, 10-15 \%$, and $5 \%$ by mass, respectively.

Table 1. Chemical compositions of the granite used in the experiments

\begin{tabular}{c|c|c|c|c|c|c|c|c|c|c}
\hline \multicolumn{10}{c}{ Chemical composition (\%) } \\
\hline $\mathrm{SiO}_{2}$ & $\mathrm{TiO}_{2}$ & $\mathrm{Al}_{3} \mathrm{O}_{2}$ & $\mathrm{Fe}_{2} \mathrm{O}_{3}$ & $\mathrm{MnO}$ & $\mathrm{MgO}$ & $\mathrm{CaO}$ & $\mathrm{Na}_{2} \mathrm{O}$ & $\mathrm{K}_{2} \mathrm{O}$ & $\mathrm{P}_{2} \mathrm{O}_{5}$ & Others \\
\hline 74.29 & 0.20 & 13.54 & 1.88 & 0.37 & 0.28 & 0.78 & 3.49 & 4.78 & 0.04 & 0.38 \\
\hline
\end{tabular}

\section{Medium}

A potato dextrose agar medium (PDA) was produced by boiling $200 \mathrm{~g}$ potato slices for $20 \mathrm{~min}$ and then filtering them through eight cotton gauze layers to remove slag. A mixture of $20 \mathrm{~g}$ glucose and $20 \mathrm{~g}$ agar were then added along with distilled water up to $1,000 \mathrm{ml}$; this mixture was then heated and stirred well before being sterilized at $121{ }^{\circ} \mathrm{C}$ for $20 \mathrm{~min}$.

We also produced a liquid PD culture medium that did not include $20 \mathrm{~g}$ agar.

\section{Isolation, purification, and screening of fungal strains}

The lichen samples we obtained from rock surfaces were washed many times, remaining fluids were collected and were then oscillated on a shaker at room temperature and $150 \mathrm{rpm}$ for $30 \mathrm{~min}$. A sterile water continuous gradient dilution (i.e., $10^{-4}, 10^{-5}$, and $10^{-6}$ ) within a $200 \mu \mathrm{L}$ suspension was then uniformly coated onto a PDA plate and placed in a constant temperature incubator at $28{ }^{\circ} \mathrm{C}$ for between six and seven days. Depending on the subsequent characteristics of the resultant fungal colony, including morphology and color, the strain species was identified and a single colony was selected, purified, and stored at $4{ }^{\circ} \mathrm{C}$ in a refrigerator. 
We then cultured each strain at $28^{\circ} \mathrm{C}, 150 \mathrm{rpm}$ for ten days for participation in rock weathering experiments. The strains which significantly released Si were then screened using an inductively coupled plasma optical emission spectrometer plasma emission spectrometer (ICP-OES)(American Vista MXP type); these experiments showed that the XF-1 strain exerted a good weathering effect and so this one was used for the remainder of this analysis.

The experimental strain was identified via its single colony morphological characteristics as well as color, hyphae, conidia, sporangia, and genomic sequence.

The gDNA of the XF-1 strain was extracted using the CTAB method (Wu et al., 2017). In this case, the volume used for the PCR reaction system was 20 L: $2 \times$ PCR reaction mix $10 \mu \mathrm{L}$; we also used $1 \mu \mathrm{L}$ of the forward primer ITS1,1 $\mu \mathrm{L}$ of the reverse primer ITS4 $\left(10 \mathrm{mmol} \cdot \mathrm{L}^{-1}\right), 1 \mu \mathrm{L}$ of template DNA, and $7 \mu \mathrm{L}$ of $\mathrm{ddH}_{2} \mathrm{O}$. This mixture enabled us to analyze and identify the gene sequence of $18 \mathrm{~S}$ rDNA with PCR reaction conditions that comprised predegeneration at $94^{\circ} \mathrm{C}$ for $5 \mathrm{~min}$, degeneration at $94{ }^{\circ} \mathrm{C}$ for 30 seconds, annealing renaturation at $55^{\circ} \mathrm{C}$ for 30 seconds, and elongation at $72{ }^{\circ} \mathrm{C}$ for one minute. This procedure was repeated over 30 cycles prior to final elongation at $72{ }^{\circ} \mathrm{C}$ for $10 \mathrm{~min}$. Amplification PCR products were then detected via $1 \%$ agarose gel electrophoresis, ethidium bromide (EB) staining, and an ultraviolet detector. The purification and sequencing of PCR products was completed by GenScript (Nanjing) Co., Ltd; all sequencing results were submitted to the GenBank database (www.ncbi.nlm.nih.gov) and analyzed using BLAST software.

\section{Spore suspension preparation}

The XF-1 strain used in this analysis was cultivated at $28^{\circ} \mathrm{C}$ for seven days and was augmented with $5 \mathrm{~mL}$ sterile water. Thus, by gently scraping spores on the surface of the agar, a suspension was filled to a $50 \mathrm{mLsterilized} \mathrm{trianglular} \mathrm{bottle,} \mathrm{into} \mathrm{which}$ several sterile glass ball had been placed in advance, and was then filtered with the sterile absorbent cotton after complete vibration fully. The final residue of this stage was washed three times with sterile water, the filtrate was collected and added to $10 \mathrm{~mL}$ with sterile water, and spore suspensions of $10^{3} \mathrm{~mL}^{-1}, 10^{5} \mathrm{~mL}^{-1}, 10^{7} \mathrm{~mL}^{-1}, 10^{9} \mathrm{~mL}^{-1}$, and $10^{11} \mathrm{~mL}^{-1}$ were then prepared.

\section{Test design and treatments}

Tests were divided into four groups, A, B, C, and D. The aim of the group A test set was to explore the influence of $A$. niger on weathered granite at different temperatures. These experiments comprised $5 \mathrm{~g}$ of granite rock powder that placed into a $250 \mathrm{~mL}$ triangle bottle, a $100 \mathrm{~mL}$ PD medium was then added and $\mathrm{pH}$ was adjusted to 7 and the whole mixture was autoclaved at $121{ }^{\circ} \mathrm{C}$ for $20 \mathrm{~min}$. Subsequent to cooling to room temperature, $10^{7} \mathrm{~mL}^{-1}$ of $5 \%$ A. niger spore suspension prepared in advance was then inoculated in a triangular bottle following a sterile operation, and cultivated at $150 \mathrm{rpm}$ and at $5{ }^{\circ} \mathrm{C}, 15^{\circ} \mathrm{C}, 28{ }^{\circ} \mathrm{C}, 32^{\circ} \mathrm{C}$ and $37^{\circ} \mathrm{C}$, respectively.

The aim of the group B series of tests was to study the influence of different $\mathrm{pH}$ value on weathered granite by $A$. niger. Thus, $5 \mathrm{~g}$ of granite rock powder was placed into a $250 \mathrm{~mL}$ triangle bottle, $100 \mathrm{~mL}$ of PD liquid medium was added, and the $\mathrm{pH}$ was adjusted to $3,5,7,9$, and 11 , respectively. The whole mixture was then autoclaved at $121{ }^{\circ} \mathrm{C}$ for $20 \mathrm{~min}$. Subsequent to cooling to room temperature, $10^{7} \mathrm{~mL}^{-1}$ of $5 \%$ A. niger 
spore suspension prepared in advance was then inoculated in a triangular bottle in a sterile manner and cultivated at $28^{\circ} \mathrm{C}$.

The aim of the group $\mathrm{C}$ set of tests was to study the influence of different generation cycles on granite weathered by A. niger. In this series, $5 \mathrm{~g}$ of granite rock powder was placed into a $250 \mathrm{~mL}$ triangle bottle, $100 \mathrm{~mL}$ of potato sucrose medium was added, the $\mathrm{pH}$ was adjusted to 7 , and the whole mixture was autoclaved at $121{ }^{\circ} \mathrm{C}$ for $20 \mathrm{~min}$. Subsequent to cooling at room temperature, $10^{7} \mathrm{~mL}^{-1}$ of $5 \%$ A. niger spore suspension from the first, second, third, fourth and fifth generations prepared in advance was inoculated in a triangular bottle in a sterile operation, and cultured at $28^{\circ} \mathrm{C}$ and $150 \mathrm{rpm}$.

The aim of the group D set of tests was to study the influence of different vaccination quantities granite weathered by $A$. niger. In this case, $5 \mathrm{~g}$ of granite rock powder was placed into a $250 \mathrm{~mL}$ triangle bottle and $100 \mathrm{~mL}$ potato sucrose liquid medium was added, the $\mathrm{pH}$ was adjusted to 7 , and the whole mixture was autoclaved at $121^{\circ} \mathrm{C}$ for $20 \mathrm{~min}$. Subsequent to cooling to room temperature, $10^{3} \mathrm{~mL}^{-1}, 10^{5} \mathrm{~mL}^{-1}, 10^{7} \mathrm{~mL}^{-1}$, $10^{9} \mathrm{~mL}^{-1}$, and $10^{11} \mathrm{~mL}^{-1}$ solutions of $5 \%$ A. niger spore suspension prepared in advance were inoculated in triangular bottles in a sterile operation and cultivated at $28{ }^{\circ} \mathrm{C}$ and $150 \mathrm{rpm}$.

Each of the group experiments discussed above was repeated in triplicate, with the spore suspension autoclaved at $121^{\circ} \mathrm{C}$ for $20 \mathrm{~min}$ used for comparisons. On day 30, $5 \mathrm{~mL}$ of the fermented liquid from each treatment was taken, centrifuged at 5,000 rpm for $10 \mathrm{~min}$ and the resultant supernatant was placed in a $50 \mathrm{~mL}$ volumetric flask, filled to a constant volume. We then added $0.05 \mathrm{~mL}$ of nitric acid $(65 \%)$ and $\mathrm{SiO}_{2}$ sample contents were detected using a plasma ICP-OES.

\section{Scanning electron microscope (SEM) observation of granite}

Treated granite residuals were collected and dried at $50{ }^{\circ} \mathrm{C}$. Each sample was then fixed, sprayed with metal, and surface characteristics on day 30 were observed using a SEM (Hitanchi-S3400N).

\section{Data analysis}

All of the data collected in this study were processed using the software Excel 2010 and variance analyses and significant difference tests were carried out using SPSS 20.0. The influence of different environmental factors on granite weathering by A. niger was analyzed using the GCAM, as outlined in this section.

The quantities of $\mathrm{SiO}_{2}$ released from the various influencing factor treatments were regarded as a reference sequence for the GCAM. Thus, $x_{0}(k)$ refers to the $\mathrm{SiO}_{2}$ released from the various treatments, temperature is $x_{1}, \mathrm{pH}$ is $x_{2}$, generation cycle is $x_{3}$, and vaccination quantity is $x_{4}$; these values comprised a sequence for comparisons, expressed as $x_{i}(i=1,2,3,4)$, while $x_{i}(k)$ denotes treatment data from the influencing factors. Applying the correlation degree formula, the extent of grey correlation between the comparison and reference sequence was then obtained, and this order was arranged in accordance; the influence of comparative sequence (i.e., influencing factors) on the reference sequence was therefore determined by applying the specific calculation steps outlined below.

A. Reference and comparison sequences were determined.

B. The sequence difference of the sequences was calculated via Equation 1. 


$$
\Delta_{i}(k)=\left|x_{0}(k)-x_{i}(k)\right|
$$

C. Maximum and minimum differences between two poles were calculated via Equations 2 and 3.

$$
\begin{gathered}
M=\max _{i} \max _{k} \Delta_{\mathrm{i}}(k) \\
m=\min _{\mathrm{i}} \min _{k} \Delta_{\mathrm{i}}(k)
\end{gathered}
$$

D. The correlation coefficient between comparison and reference sequences was then determined based on different influencing factors using the transformation data, via Equation 4.

$$
r_{o i}(k)=\frac{m+\xi M}{\Delta_{i}(k)+\xi_{M} M}
$$

In this expression, $\xi$ denotes the identification coefficient, usually 0.5 .

The grey correlation degree was calculated via the Equation 5.

$$
r_{\text {oi }}=\frac{1}{n} \sum_{k=1}^{n} r_{\text {oi }}(k)
$$

In this expression, $r_{o i}$ denotes the grey correlation degree between the comparison sequence, $x_{i}$, and the reference sequence, $x_{o}$. This calculation process was performed using the grey breeding computer decision system (Li et al., 2016; Gao and Xu, 2016).

\section{Results and discussion}

\section{Screening for highly-effective Si-releasing fungi}

The amounts of $\mathrm{SiO}_{2}$ released by fermentation broth of the 18 fungi strains severally cultured for 10 days was was determined. Results show that the amount of $\mathrm{SiO}_{2}$ released by fermentation broth of XF-1 strain $\left(28.44 \mathrm{mg} \cdot \mathrm{L}^{-1}\right)$ was significantly higher than that of other fungi strains and control group (Fig. 1). This result indicates that both the growth and metabolism of this fungal strain effectively promotes the dissolution of granite and increases Si release. Strain XF-1 was therefore selected as the target for further study.

\section{Isolation, purification, and identification of strain XF-1}

The XF-1 strain possesses well-developed hyphae that are greatly branched and is dark brown with a spherical top capsule. The conidium of this strain is spherical in shape and possesses black or dark brown chrysanthemum-shaped heads produced vertically from specialized hyphae cells with thick and swollen walls (Fig. 2). The XF-1 strain was initially judged to be A. niger based on these morphological characteristics; further $18 \mathrm{~S}$ rDNA amplification and sequencing were also performed and these results confirm $99 \%$ homology with $A$. niger. 


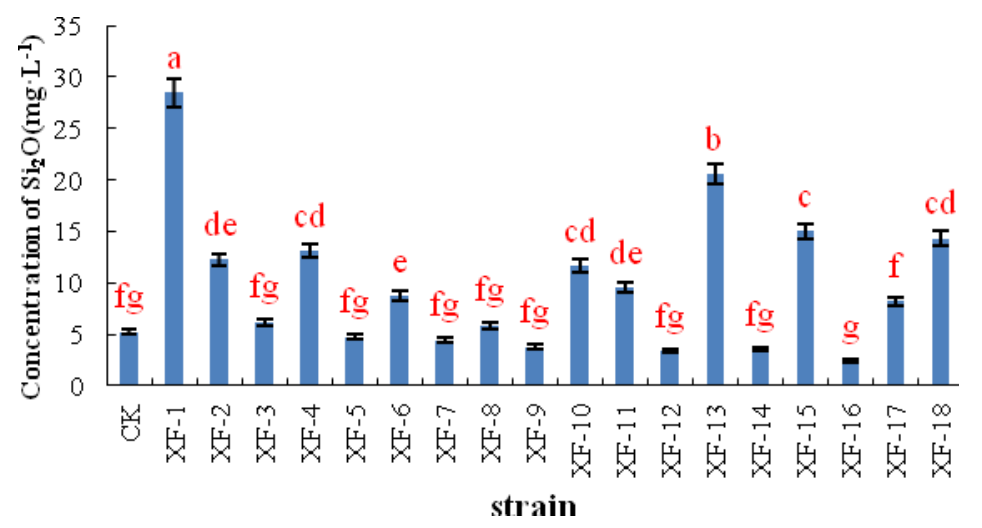

Figure 1. Dissolution action of different fungus strains to granite on day 10. (Standard error bars were marked. Significant differences at 0.05 level were analyzed using Tukey test by SPSS Version 20.0)
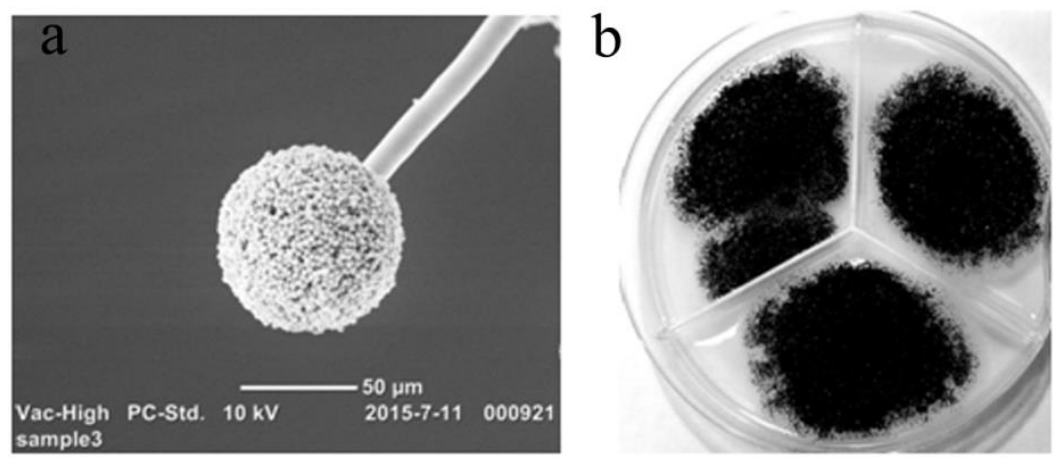

Figure 2. Electron microscopy (SEM) image and colonial morphology of XF-1 strain. a. Conidium and conidiophore for XF-1 strain. $\boldsymbol{b}$. Colonial morphology of XF-1 strain on PDA

\section{The influence of environmental factors on Si release from granite}

The effects of the four environmental factors considered here (i.e., temperature, $\mathrm{pH}$, generation cycle, and vaccination quantity) on granite weathering by the XF- 1 strain are summarized in Table 2. Results show that, under experimental conditions with A. niger, the $\mathrm{SiO}_{2}$ content in dissolution was 7.05 times higher on average than the control group (without $A$. niger); these experimental results show that the effect of granite weathering by the XF-1 strain was significantly enhanced compared to the control group (without A. niger).

\section{The effects of different culture temperatures on granite weathering}

The effects of different culture temperature on granite weathering was significant in this experiment $(p<0.05)$ (Table 2). Data show that across all five temperature treatments, the Si-releasing effect of granite weathered by A. niger at $28{ }^{\circ} \mathrm{C}$ was the highest, significantly better than other treatments $(p<0.05)($ Table 2$)$. Lower, or higher, temperatures that this optimal level were not conducive to granite weathering, a result that is generally consistent with the earlier work of Štyriaková's research on the effects of different temperatures on the weathering of basalt, granite, and gneiss by Bacillus mucilaginosus (Štyriaková et al., 2012). 
Table 2. Effects of different environmental factors on the weathered granite by A. niger

\begin{tabular}{|c|c|c|c|c|}
\hline \multicolumn{2}{|c|}{ Treatment } & \multirow{2}{*}{\begin{tabular}{|c|}
$\begin{array}{c}\text { Mass concentration } \\
\text { of } \mathbf{S i}\left(\mathbf{m g} \cdot \mathbf{L}^{\mathbf{- 1}}\right)\end{array}$ \\
$48.86 \pm 1.62 \mathrm{c}$ \\
\end{tabular}} & \multirow{2}{*}{\begin{tabular}{|c|}
$\begin{array}{l}\text { Mass concentration of } \\
\text { Si for control }\left(\mathbf{m g} \cdot \mathbf{L}^{-1}\right)\end{array}$ \\
9.06
\end{tabular}} & \multirow{2}{*}{\begin{tabular}{|c|}
$\begin{array}{c}\text { Increased times } \\
\text { than control }\end{array}$ \\
5.39
\end{tabular}} \\
\hline \multirow{5}{*}{$\begin{array}{c}\text { Temperature } \\
\left({ }^{\circ} \mathrm{C}\right)\end{array}$} & 5 & & & \\
\hline & 15 & $71.25 \pm 2.91 b$ & 9.62 & 7.41 \\
\hline & 28 & $95.63 \pm 1.62 \mathrm{a}$ & 11.22 & 8.52 \\
\hline & 32 & $67.89 \pm 3.26 b$ & 11.84 & 5.73 \\
\hline & 39 & $50.26 \pm 1.89 \mathrm{c}$ & 12.82 & 3.92 \\
\hline \multirow{5}{*}{$\mathrm{pH}$ value } & 3 & $123.63 \pm 4.43 \mathrm{a}$ & 14.20 & 8.71 \\
\hline & 5 & $110.86 \pm 2.24 b$ & 12.42 & 8.93 \\
\hline & 7 & $95.63 \pm 2.54 b$ & 11.22 & 8.52 \\
\hline & 9 & $64.69 \pm 1.54 \mathrm{c}$ & 11.84 & 5.46 \\
\hline & 11 & $40.32 \pm 1.63 \mathrm{~d}$ & 14.04 & 2.87 \\
\hline \multirow{5}{*}{ Generation cycle } & First generation & $76.58 \pm 3.01 \mathrm{~d}$ & 11.22 & 6.83 \\
\hline & Second generation & $82.56 \pm 3.48 b c$ & 11.84 & 6.98 \\
\hline & Third generation & $95.63 \pm 1.54 \mathrm{c}$ & 14.02 & 6.82 \\
\hline & The fourth generation & $110.74 \pm 3.38 \mathrm{ab}$ & 13.04 & 8.49 \\
\hline & The fifth generation & $116.59 \pm 2.86 \mathrm{a}$ & 13.42 & 8.69 \\
\hline \multirow{5}{*}{$\begin{array}{l}\text { Vaccination } \\
\text { quantity }(\text { spore } \\
\left.\text { number } \cdot \mathrm{mL}^{-1}\right)\end{array}$} & $10^{3}$ & $75.78 \pm 1.88 \mathrm{~b}$ & 10 & 7.58 \\
\hline & $10^{5}$ & $88.06 \pm 3.03 \mathrm{a}$ & 11.02 & 7.99 \\
\hline & $10^{7}$ & $95.63 \pm 1.68 \mathrm{a}$ & 11.22 & 8.52 \\
\hline & $10^{9}$ & $68.03 \pm 1.96 b c$ & 10.04 & 6.78 \\
\hline & $10^{11}$ & $65.95 \pm 1.42 \mathrm{c}$ & 9.64 & 6.84 \\
\hline Mean & & & & 7.05 \\
\hline
\end{tabular}

Different letters in the same column indicate significant difference in the $5 \%$ level

It is noteworthy that the temperatures used in this experiment are related to annual changes in Suzhou, Jiangsu Province, China. The spring and autumn in this region are short, while the summer and winter are long; $5^{\circ} \mathrm{C}$ is the lowest average monthly temperature, while $15^{\circ} \mathrm{C}$ is the annual mean, $28^{\circ} \mathrm{C}$ is the average temperature of the hottest month, $32{ }^{\circ} \mathrm{C}$ is the maximum temperature of the hottest month, and $39^{\circ} \mathrm{C}$ is the extreme temperature of the region. It is also the case that annual changes of temperature across this region obviously alternate; it has been shown that changes in temperature alternation can easily cause significant damage to a granite body (Ming and Fan, 2017), promoting rock weathering. Thus, the two characteristics of this region, alternate changes in temperature and an average of $28{ }^{\circ} \mathrm{C}$ in the hottest month, are both very beneficial to granite weathering.

\section{The effects of $p H$ on granite weathering}

We show that different $\mathrm{pH}$ values exerted a significant influence on granite weathering effects (Table 2). Results show that at $\mathrm{pH}$ value of 3, 5, 7, 9, and 11, the $\mathrm{SiO}_{2}$ contents of granite dissolved by the XF-1 strain for 30 days resulting in 123.63 $\mathrm{mg} \cdot \mathrm{L}^{-1}, 110.86 \mathrm{mg} \cdot \mathrm{L}^{-1}, 95.63 \mathrm{mg} \cdot \mathrm{L}^{-1}, 64.69 \mathrm{mg} \cdot \mathrm{L}^{-1}$, and $40.32 \mathrm{mg} \cdot \mathrm{L}^{-1}$, respectively, fold increases of 8.71, 8.93, 8.52, 5.46, and 2.87 compared to the control (without XF-1 strain). This means that the more acidic the fermentation liquid, the better the Si-release 
effect. Indeed, when the $\mathrm{pH}$ value was 3, the granite weathering effect was best, significantly different $(p<0.05)$ to weakly acidic, neutral, and alkaline conditions.

In terms of bacterial growth, when the $\mathrm{pH}$ value of the fermentation liquid transitioned from acid to alkaline, the number of mycelium pellets formed by A. niger was reduced within the cultivation system. In contrast, when the $\mathrm{pH}$ value was 9 or 11 , most rock powder was not packed, and the $\mathrm{SiO}_{2}$ content in solution was low; this further illustrates the fact that $\mathrm{pH}$ value is advantageous to granite weathering in acidic regions.

\section{Generation cycle effects on granite weathering}

We also show that the granite weathering action of different generation cycles was significantly different (Table 2). Data reveal that when the granite was dissolved by the XF-1 strain for 30 days, the $\mathrm{SiO}_{2}$ content in media from the first, two, three, four, and five generations was $76.58 \mathrm{mg} \cdot \mathrm{L}^{-1}, 82.56 \mathrm{mg} \cdot \mathrm{L}^{-1}, 95.63 \mathrm{mg} \cdot \mathrm{L}^{-1}, 110.74 \mathrm{mg} \cdot \mathrm{L}^{-1}$, and $116.59 \mathrm{mg} \cdot \mathrm{L}^{-1}$, respectively, fold increases of $6.83,6.98,6.82,8.49$, and 8.69 times compared to the control (without XF-1 strain). As generation cycle increased, $\mathrm{SiO}_{2}$ content in granite culture media also gradually increased; indeed, the Si-releasing effect of granite weathered by the XF-1 strain was best in the fifth generation, and there were no significant differences between this generation and the fourth one in terms of weathering effects. Differences between the fifth and other generations were significant $(p<0.05)$; this means that the influence of generation cycle on the weathering effect of granite is likely to increase the activity of $A$. niger in concert with generation cycle.

\section{The effect of vaccination quantity on granite weathering}

We show that when granite was dissolved by the XF-1 strain for 30 days in our experiments, the contents of $\mathrm{SiO}_{2}$ recovered when the vaccination quantity was $10^{3} \mathrm{~mL}^{-}$ 1, $10^{5} \mathrm{~mL}^{-1}, 10^{7} \mathrm{~mL}^{-1}, 10^{9} \mathrm{~mL}^{-1}$, and $10^{11} \mathrm{~mL}^{-1}$ were $75.78 \mathrm{mg} \cdot \mathrm{L}^{-1}, 88.06 \mathrm{mg} \cdot \mathrm{L}^{-1}$, $95.63 \mathrm{mg} \cdot \mathrm{L}^{-1}, 68.03 \mathrm{mg} \cdot \mathrm{L}^{-1}$, and $69.95 \mathrm{mg} \cdot \mathrm{L}^{-1}$ respectively. These values represent fold increases of $7.58,7.99,8.52,6.78$, and 6.84 times those of the control (without XF-1 strain). Data show that the Si-releasing ability of the $10^{7} \mathrm{~mL}^{-1}$ vaccination quantity was the strongest, there was no significant difference between $10^{7} \mathrm{~mL}^{-1}$ and the $10^{5} \cdot \mathrm{mL}^{-1}$ dilutions, but there was a distinct change between the $10^{7} \mathrm{~mL}^{-1}$ and other vaccination quantities $(p<0.05)$. The relationship between vaccination quantity and dissolved $\mathrm{SiO}_{2}$ content had a clear relationship; when the vaccination quantity increased from $10^{3} \mathrm{~mL}^{-1}$ to $10^{5} \mathrm{~mL}^{-1}$, the content of dissolved $\mathrm{SiO}_{2}$ gradually increased, but when the quantity increased to $10^{7} \mathrm{~mL}^{-1}$, dissolved $\mathrm{SiO}_{2}$ reached its maximum level. Data show that when the vaccination quantity continued to increase, the content of dissolved $\mathrm{SiO}_{2}$ decreased, a result which indicates that volume of release is closely related to the ability of A. niger to weather this rock. The use of an appropriate vaccination quantity might therefore improve the weathering ability of A. niger; in a limited space, however, it is clear that the vaccination quantity of microorganisms controls weathering ability. The reasons for this phenomenon might include the fact that the growth of microorganisms is related to nutrient composition, and all the experiments performed here were carried out closed systems where both the pace and nutrition were limited. These systems cannot, therefore, enable sufficient microbial individuals to reproduce, which might have affected their ability to weather granite. This phenomenon is similar, however, to environments in which there is competition between rock surface organisms in natural conditions. 


\section{The relationship between environmental factors and A. niger granite weathering}

As the environmental factors discussed here all exert a significant on the granite weathering of $A$. niger, it is necessary to determine which are more important. We therefore evaluated the relationship between environmental factors and the weathering action of this bacterium. Data show that, in general, the influence of various factors on granite weathering is non-linear and thus hard to unravel using traditional statistical approaches. Our use of grey relational analysis can overcome this defect (Li et al., 2016; $\mathrm{Gao}$ and $\mathrm{Xu}, 2016$ ); we applied this approach to analyze the relationships between temperature, $\mathrm{pH}$ value, vaccination quantity, and generation cycle versus the weathering effects of $A$. niger (Table 3). Our results show that the most important factor influencing the weathering of $A$. niger was $\mathrm{pH}\left(x_{2}\right)$, followed by vaccination quantity $\left(x_{4}\right)$, temperature $\left(x_{1}\right)$, and the influence of generation cycle $\left(x_{3}\right)$.

Table 3. Analysis of grey relational degree between different environmental factors and A. niger weathered granite

\begin{tabular}{l|c|c|c|c}
\hline Enviromental factor & Temperature $\left(x_{1}\right)$ & $\mathbf{p H}$ value $\left(\boldsymbol{x}_{\mathbf{2}}\right)$ & Generation cycle $\left(\boldsymbol{x}_{3}\right)$ & Vaccination quantity $\left(\boldsymbol{x}_{\mathbf{4}}\right)$ \\
\hline Grey relational degree & 0.56 & 0.82 & 0.50 & 0.63 \\
\hline
\end{tabular}

It is clear that acidolysis is one important way to promote the microbial weathering of minerals (Wu et al., 2018; Welch and Ullman, 1993; Toyama and Terakado, 2015), and comprises both inorganic and organic acids (Lian, 2008). Data show that given the same $\mathrm{pH}$ conditions, organic acids are more likely to accelerate the dissolution of minerals than their inorganic counterparts because the former can combine proton exchange with ligand complexes in weathering to form a complex enhancing rock dissolution (Štyriaková et al., 2012). An A. niger-granite aggregate was formed on the rock surface in this study to comprise a micro-environment (Fig. 3b); this efficiently enriched organic acids (Zhu et al., 2014; Gadd et al., 2014; Wang et al., 2015), and strengthened the synergetic weathering of organic acids with polysaccharides, hyphae, and adsorbed $\mathrm{SiO}_{2}$ released to produce a concentration gradient in the fermented liquid, especially oxalic and citric acids. A. niger is capable of producing six organic acids: oxalic acid, citric acid, malic acid, tartaric acid, acetic acid and succinic acid, so that the $\mathrm{pH}$ of its fermentation liquid is reduced to the lowest value on the $10 \mathrm{~d}$, and the weathering effect of granite is the optimum at this moment (Wu et al., 2018).

This process could therefore be utilized to complete slope ecological restoration, involving the initial adjustment of matrix soil $\mathrm{pH}$ values and the use of $A$. niger as a fungal source. The amount of $A$. niger can then be appropriately increased to improve the microbial weathering of granite, and can achieve soil formation, vegetation restoration, and improvements to the ecological environment in the short term.

\section{SEM observations of granite surface changes}

A SEM micrograph of granite weathered by A. niger on day 30 reveals that this bacterium produced a significant weathering effect (Fig. 3). This image also shows, however, that no obvious dissolution trace was observed on the rock surface without $A$. niger because this active bacterium was absent (Fig. 3a), and there were obvious corrosion traces and a number of mycelia on the granite surface by day 30 (Fig. 3b) (in 
this case, the granite surface weathered by A. niger at a temperature of $28{ }^{\circ} \mathrm{C}$ on day 30 was used as an example). Hyphae interspersed and penetrated the rock surface via cracks and other weak positions, intruded into the interior, produced mechanical damage, loosened the rock structure, increased the contact area, and formed a hyphaemineral aggregate, making the granite surface rough. This result was previously noted by Lian (2014), Peng et al. (2015), and Toyama and Terakado (2015).
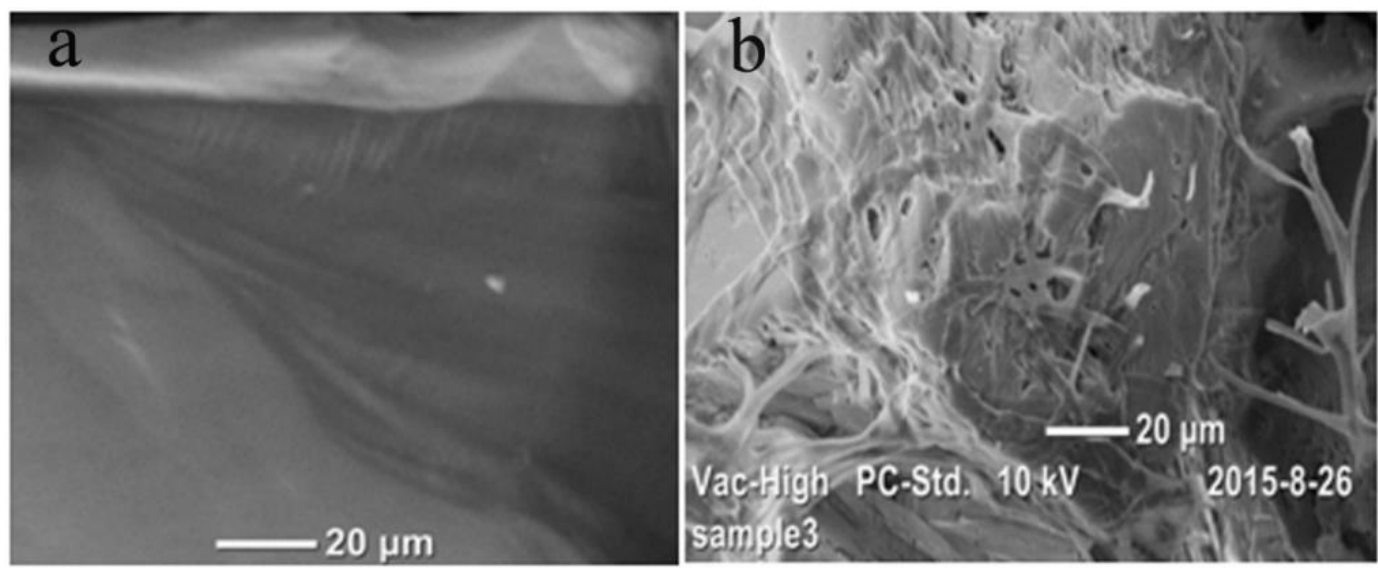

Figure 3. Scanning electron micrograph (SEM) of granite. a. The surface of the granite without A. niger. $\boldsymbol{b}$. The surface of the granite affected by A. niger

Studies have also shown that $A$. niger is widely distributed in soil and comprises an important component of the microbial population. This bacterium is capable of weathering black and micas, common feldspar, phosphate ore, olivine and copper ore tailings (Li, 2015a; Lian, 2008; Sun et al., 2014; Li et al., 2015b, c; Diao et al., 2015; Fomina, 2014), and can corrode $\mathrm{P}_{2} \mathrm{O}_{5}, \mathrm{~K}_{2} \mathrm{O}$ and other elements to promote the growth of crops (Dong and Lian, 2014). We show that A. niger can also efficiently weather granite in this analysis, and the dissolution quantity of $\mathrm{SiO}_{2}$ in the fermentation broth on day 30 was 7.05 times more than the control group (without A. niger) (Table 2). This result further confirms the acceleration of A. niger on granite weathering and corrosion of $\mathrm{Si}$ element from the perspective of practice. Si element is not an essential but a beneficial element for plants. Si can make plants with green stems strong, promote root growth, increase plant fruit, improve crop quality, and also make plants resistant to diseases, droughts, insects and lodging. It can also improve soil structure and increase the content of alkali-hydrolysis nitrogen, available potassium and available silicon in soil. In particular, most soils in south China are seriously deficient in silicon in acid soil, and the available silicon content is very low (Chen et al., 2016). Our research results showed that once applied to the remediation of abandoned rock mining areas, XF-1 strain can promote the dissolution of effective silicon in soil, increase the content of available nitrogen, phosphorus and potassium in soil, improve soil nutrient insufficiency, and promote the growth of plants.

A number of issues and obstacles nevertheless remain if $A$. niger is to be used for environmental restoration research. In natural conditions, the $\mathrm{pH}$ value that is conducive for the activity of this microbe is very difficult to adjust, while suitable growth temperatures and humilities are also hard to maintain, and the various factors do not worked independently. Therefore, further research is needed to explore these questions. 


\section{Conclusions}

A XF-1 strain that can weather granite highly effectively was isolated in our experiments from a granite surface. This bacterium was identified as A. niger via morphological comparisons and on the basis of $18 \mathrm{~S}$ rDNA gene sequences. This strain provides a good fungal source that can be used to solve the issue of rapid soil formation on bare rock within abandoned mining areas and also presents a new approach that can be used for the ecological restoration of degraded habitats.

The bacterium A. niger exerts an obvious acceleration effect on granite weathering. Our SEM observations reveal the presence of a large number of mycelia and obvious corrosion pits on rock surfaces. In the presence of $A$. niger, the dissolved $\mathrm{SiO}_{2}$ content was 7.05 times higher on average than just the control (without $A$. niger).

We introduce the use of a GCAM in this experiment to quantitatively assess the degree of influence of each environmental factor on granite weathering by A. niger for the first time. Results show that $\mathrm{pH}$ is the dominant factor affecting granite weathering by $A$. niger, followed by vaccination quantity and temperature, while the influence of generation cycle was the least important. Data show that when the $\mathrm{pH}$ value was 3 , the vaccination quantity was $10^{7} \cdot \mathrm{mL}^{-1}$, the fifth generation cycle was used, and the temperature was $28^{\circ} \mathrm{C}$, the best effects were obtained. In cases where temperature and other environmental conditions are suitable for microbial growth, soil formation velocity on exposed rock will be accelerated via microorganisms entering cracks throughout mineral weathering.

Acknowledgements. This research was supported by the positioning research project of Forest Ecosystem of Changjiang River Delta in Jiangsu Province, the Engineering Project 'Three New' for Forestry in Jiangsu Province (lysx [2013] 10), a project funded by the Priority Academic Program Development of Jiangsu Higher Education Institutions, the open project of the Key Laboratory of Soil and Water Conservation and Ecological Restoration in Jiangsu Province, and a Fund Project of the Anyang Institute of Technology (YJJ2015011).

\section{REFERENCES}

[1] Barker, W., Banfield, J. (1996): Biologically versus inorganically mediated weathering reactions: relationships between minerals and extracellular microbial polymers in lithobiontic communities. - Chemical Geology 132(1-4): 55-69.

[2] Bennett, P. C., Rogers, J. R., Choi, W. J. et al. (2001): Silicates, silicate weathering, and microbial ecology. - Geomicrobiology Journal 18(1): 3-19.

[3] Borland, H., Amobrosini, V., Indgreen, A. et al. (2016): Building theory at the intersection of ecological sustainability and strategic management. - Journal of Business Ethics 135(2): 293-307.

[4] Castro, I. M., Fietto, J. L. R., Vieira, R. X. et al. (2000): Bioleaching of zinc and nickel from silicates using Aspergillus niger cultures. - Hydrometallurgy 57(1): 39-49.

[5] Chen G, Luo, Z. X., Shi, F. Z. et al. (2016): Effect of a new type silicon fertilizer application on yield of two lines hybrid rice. - Soil and Fertilizer Sciences in China 55(2): 109-113 (in Chinese).

[6] Cheng, Y. X., Duan, Y. G., Li, G. H. et al. (2015): Accumulation of freeze-thaw weathering of rock debris flow provenance test study. - Disaster Science 30(2): $46-50$ (in Chinese).

[7] Chiang, Y. W., Santos, R. M., Van Audenaerde, A. et al. (2014): Chemoorganotrophic bioleaching of olivine for nickel recovery. - Minerals 4(2): 553-564. 
[8] Gadd, G. M., Bahriesfahani, J., Li, Q. W. et al. (2014): Oxalate production by fungi: significance in geomycology, biodeterioration and bioremediation. - Fungal Biology Reviews 28(2-3): 36-55.

[9] Gao, J. J., Xu, G. (2016): Gray correlation analysis of meteorological disasters and crop yield in chongqing. - Journal of Southwest University (Natural Science Edition) 38(2): 32-36 (in Chinese).

[10] Diao, N. N., Li, G. Y., Wang, Y. D. et al. (2015): Bioleaching of copper from high alkaline copper ore tailings with Aspergillus niger. - The Chinese Journal of Process Engineering 15(1): 132-135 (in Chinese).

[11] Dong, C. L., Lian, B. (2014): Comparing the bio-weathering effects for biotite by Bacillus mucilaginosus and Aspergillus niger. - Bulletin of Mineralogy, Petrology and Geochemistry 33(6): $772-777$ (in Chinese).

[12] Fomina, M. O. (2014): Variability of coordination complexes of copper accumulated within fungal colony in the presence of copper-containing minerals. - Biotechnologia Acta 7(2): 63-69.

[13] Hu, J., Lian, B., Yu, J. P. et al. (2011): Capability and mechanism of potassium releasing from potassium-bearing minerals by Asperillus niger. - Bulletin of Mineralogy petrology and Geochemistry 30(3): 277-285.

[14] Li, A. G., Song, X. X., Wu, C. X. (2016): The grey correlation analysis between agronomic trait and yield in Triticum aestivum. - Crop Research 30(1): 18-21 (in Chinese).

[15] Li, G., Diao, N., Wang, Y. et al. (2015a). Bioleaching of copper from tailings by fermentation broths of Aspergillus niger in pellet form. - Journal of Chemical Industry and Engineering 66(2): 717-722 (in Chinese).

[16] Li, H., Cai, L., Yao, Q. Z., Zhou, G. T. (2015b). Fungal involvement in biogeological processes and application to environmental bioremediation. - Geological Journal of China Universities 21(3): 382-394 (in Chinese).

[17] Li, J. F., Zhang, W. J., Lu, J. W. et al. (2015c). Effects of citrate dissolving surface and altering microstructure of biotite. - Acta Pedologica Sinica 52(2): 329-335 (in Chinese).

[18] Li, Y., Li, F. C., Yang, G. et al. (2017): Comparing elements dissolution from biotite bioweathering by bacteria and fungi. - Chinese Journal of Soil Science 48(1): 86-93 (in Chinese).

[19] Lian, B. (2014): Research progress of mineral-microbe interactions: a comment for geomicrobiology column. - Bulletin of Mineralogy, Petrology and Geochemistry 33(6): 759-763 (inChinese).

[20] Lian, B., Chen, Y., Zhu, L. (2008): Progress in the study of the weathering of carbonate rock by microbes. - Earth Science Frontiers 15(6): 90-99 (in Chinese).

[21] Lü, J., Tian, X. H., Yan, H. et al. (2015): Effect of Aspergillus niger fermentation liquid on the growth of wheat seedlings in calcareous soil. - Journal of Northwest A\&F University (Natural Sciences Edition) 43(5): 100-106 (in Chinese).

[22] Ming, X. F., Fan, C. W. (2017): Effect of freezing-thawing Cycle on the physical and Mechanical properties of granite. - Science Technology and Engineering 17(13): 261265.

[23] Peng, Y., Song, M., Pedruzzi, I. et al. (2015): K-release and weathering of muscovite by Cenococcum geophilum. - Acta Microbiologica Sinica 55(3): 282-291.

[24] Pratas, J., Prasad, M., Freitas, H. et al. (2005): Plants growing in abandoned mines of Portugal are useful for biogeochemical exploration of arsenic, antimony, tungsten and mine reclamation. - Journal of Geochem Explor 85(3): 99-107.

[25] Qi, X., Wang, K., Zhang, C. (2013): Effectiveness of ecological restoration projects in a karst region of southwest China assessed using vegetation succession mapping. Ecological Engineering 54: 245-253. 
[26] Ramos, M. E., Garcia-Palma, S., Rozalen, M. et al. (2014): Kinetics of montmorillonite dissolution: an experimental study of the effect of oxalate. - Chemical Geology 363(1): 283-292.

[27] Song, M., Peng, Y. X., Pedruzzi, I. et al. (2015): Bioweathering and K release of Kbearing minerals by Penicillium oxalicum. - Microbiology China 42(7): 1410-1417 (in Chinese).

[28] Song, R. Q., Lian, B. (2014): Effect of Aspergillusniger on the impurity removal of quartz sands. - Bulletin of Mineralogy Petrology and Geochemistry 33(6): 784-789.

[29] Štyriaková, I., Štyriak, I., Oberhansli, H. (2012): Rock weathering by indigenous heterotrophic bacteria of Bacillus spp. at different temperature: a laboratory experiment. Mineralogy and Petrology 105(3-4): 135-144.

[30] Sun, D. S., Yin, J. M., Chen, Y. et al. (2014): Effect of crystal structures of potassiumbearing minerals on Aspergillus niger growth metabolism and potassium and silicon release. - Scientia Agricultura Sinica 47(3): 503-513 (in Chinese).

[31] Tang, J. T., Pei, X. J., Pei, Z. et al. (2016): Study on rock injured in freeze-thaw cycles. Science, Technology and Engineering 16(27): 101-105 (in Chinese).

[32] Tang, X. P., Chen, Y., Cao, F. et al. (2014): Breeding of potassium-dissolved Fungi by protoplast mutagenesis and bioleaching potassium-rich shale. - Journal of Central South University (Science and Technology) 45(10): 3330-3338 (in Chinese).

[33] Toyama, K., Terakado, Y. (2015): Differential dissolution technique for the geochemical separation of the calcite and dolomite of dolomitic limestones. - Geochemical Journal 49(5): 567-570.

[34] Wang, R. R., Wang, Q., He, L. Y. et al. (2015): Isolation and the interaction between a mineral-weathering Rhizobium tropici Q34 and silicate minerals. - World Journal of Microbiology and Biotechnology 31(5): 747-753.

[35] Wang, S. J. (2017): Effect of humidity change on rock weathering. - Value Engineering 36(2): 109-110 (in Chinese).

[36] Welch, S. A., Ullman, W. J. (1993): The effect of organic acids on plagioclase dissolution rates and stoichiometry. - Geochimicaet Cosmochimica Acta 57(12): 2725-2736.

[37] Williams, C. H., Steinbergs, A. (1959): Soil sulphur fractions as chemical indices of available sulphur in some Australian soils. - Journal of Vacuum Science and Technology 17(6): 3265-3271.

[38] Wu, Q. F., Fu, L., Lu, Z. F. (2016): Purification and molecular identification experiments of microbe in soil. - Journal of Anyang Institute of Technology 15(4): 27-29 (in Chinese).

[39] Wu, Y. W., Zhang, J. C., GuoX. P. et al. (2017a): Identification of efficient strain applied to mining rehabilitation and its rock corrosion mechanism: based on boosted regression tree analysis. - Environmental Science 38(1): 283-293 (in Chinese).

[40] Wu, Y. W., Zhang, J. C., Wang, L. J. et al. (2017b): A rock-weathering bacterium isolated from rock surface and its role in ecological restoration on exposed carbonate rocks. - Ecological Engineering 101(1): 162-169.

[41] Wu, Q. F., Hu, H. B., Zhang, X. (2018): Effect of Aspergillus niger and its metabolites on weathering of granite. - Journal of Nanjing Forestry University (Natural Sciences Edition) 42(1): 81-88 (in Chinese).

[42] Zhu, Y. G., Duan, G. L., Cheng, B. D. et al. (2014): Mineral weathering and element cycling in soil -microorganism-plant system. - Science China: Earth Sciences 1(6): 11071116 (in Chinese). 